\title{
EFEKTIFITAS MODEL PROBLEM BASED INSTRUCTION TERHADAP KETERAMPILAN PROSES SAINS MAHASISWA PADA MATA KULIAH KONSEP SAINS
}

\section{Ivayuni Listiani}

Fakultas Keguruan dan Ilmu Pendidikan, Universitas PGRI MADIUN ivayuni@unipma.ac.id

\begin{abstract}
This research aims to find out the effectiveness of Problem Based Instruction model on science process skills of students in the subject of science concepts II PGRI Madiun University. This research was a quasi experiment with quantitative approach. The research design was Posttest Only Control Group Design by using model Problem Based Instruction in the experimental group and the lecture method varies in the control group. The study population was the whole second semester students Prodi PGSD PGRI Madiun University. The sampling technique used cluster random sampling, in order to obtain semeseter 2 class $2 D$ as an experimental group and $2 C$ as a control group. The data collection technique using a multiple choice test and essay, observation sheets, as well as their academic papers. The hypothesis testing using t-test. Normality test was performed using Kolmogorov-Smirnov test with significance of control class 0,332 and experiment class 0,538. Homogeneity test using Levene's test with significance level of 0.532. Hypothesis test results obtained a significance level of 0.00 so that the results of this study concluded that the learning model Problem Based Instruction is effective against science process skills of students in the subject of science concepts II PGRI Madiun University.
\end{abstract}

Keywords: Model of Learning, Problem Based Instruction, Science Process Skills, Science Concepts.

\section{PENDAHULUAN}

Pendidikan merupakan sesuatu yang bersifat dinamis sehingga selalu menuntut adanya suatu perbaikan yang bersifat terus menerus. Seiring dengan perkembangan ilmu pengetahuan dan teknologi tersebut, setiap negara dituntut untuk menciptakan sumber daya manusia yang berkualitas, yaitu manusia yang mempunyai kesiapan mental dan kemampuan berpartisipasi mengembangkan ilmu pengetahuan dan teknologi sehingga dapat meningkatkan kualitas bangsa itu sendiri. Pendidikan bertujuan untuk memberikan pembelajaran yang dapat mengajarkan berbagai hasil belajar seperti bagaimana menumbuhkan sikap positif, karakter, dan melatihkan keterampilan mengambil keputusan serta keterampilan-keterampilan untuk berhasil hidup di abad 21 (Nurmasari, Kusmayadi, Riyadi, 2014). Keterampilan abad 21 yang sekarang menjadi pusat perhatian peneliti pendidikan sains antara lain adalah Learning and Innovation Skills dan Life and Career Skills (Ibrahim, 2012).

Pendidikan yang sesuai dengan perkembangan abad 21 menurut Amir (2010: 1) merupakan pendidikan yang lebih mengandalkan pada pengembangan keterampilan 
proses yang meliputi, keterampilan berpikir, keterampilan pemecahan masalah, keterampilan berkomunikasi untuk mendukung optimalisasi pencapaian pendidikan. Pembelajaran IPA yang pada hakekatnya merupakan pengetahuan yang berdasarkan fakta, hasil pemikiran dan produk hasil penelitian yang dilakukan para ahli, sehingga perkembangan pembelajaran IPA diarahkan pada produk ilmiah, metode ilmiah dan sikap ilmiah yang dimiliki mahasiswa dan akhirnya bermuara pada peningkatan kualitas mahasiswa.

Pendidikan berdasarkan standar menetapkan adanya standar nasional sebagai kualitas minimal warga negara yang dirinci menjadi standar isi, standar proses, standar kompetensi lulusan, standar pendidik dan tenaga kependidikan, standar sarana dan prasarana, standar pengelolaan, standar pembiayaan, dan standar penilaian pendidikan (Yayu, 2017). Peningkatan kualitas dapat dilakukan melalui berbagai hal melalui pemberdayaan proses pembelajaran. Proses pembelajaran belum sepenuhnya mengakomodasikan mahasiswa untuk terlibat secara aktif dalam pembelajaran sehingga mahasiswa terkesan pasif. Kepasifan mahasiswa berdampak pada kurang tertariknya dalam kegiatan pembelajaran sehingga menyebabkan rendahnya KPS mahasiswa dalam berkomunikasi untuk mengungkapkan apa yang kurang dimengerti. Hasil TIMSS (Trends in International Mathematics and Science Studies) pada tahun 2011, menunjukkan bahwa hasil sains Indonesia berada pada urutan ke-40 dari 42 negara dengan nilai rata-rata sebesar 406. Hasil serupa juga ditunjukkan dalam studi PISA (Programme for International Student Assessment) dimana skor Indonesia kembali turun menjadi 382 dan menduduki peringkat ke-64 dari 65 negara yang mengikuti studi PISA pada tahun 2012. Keadaan tersebut disebabkan oleh rendahnya kemampuan anak Indonesia dalam kemampuan mengidentifikasi masalah ilmiah, menggunakan fakta ilmiah, memahami sistem kehidupan, dan memahami penggunaan peralatan sains (Pusat Penilaian Pendidikan Balitbang Kemendikbud, 2011).

Proses pembelajaran di tingkat perguruan tinggi lebih bersifat transfer of knowledge sehingga kurang memberdayakan mahasiswa dalam pembelajaran. Mahasiswa kurang berkembang secara mandiri melalui penemuan dalam proses memecahkan masalah. Pembelajaran IPA seharusnya lebih memberdayakan pada proses karena melalui proses pembelajaran mahasiswa akan memperoleh ilmu pengetahuan yang lebih bermakna. Kondisi pembelajaran harus diperbaiki yaitu dengan berbagai pendekatan, model dan metode pembelajaran. Model pembelajaran dapat didefinisikan sebagai kerangka berpikir yang menuntun seseorang untuk merancang dan melaksanakan pembelajaran (Arends, 2002). Pemilihan model pembelajaran yang tepat merupakan suatu alternatif dalam usaha meningkatkan kualitas pembelajaran, agar siswa dapat mudah memahami apa yang dipelajari (Hendracipta, 2017). Oleh karena itu setiap model pembelajaran bercirikan sintaks atau langkah-langkah yang harus diikuti di dalam pengimplementasiannya. Setiap model pembelajaran memiliki karakteristik dan tujuan khusus untuk apa model tersebut dikembangkan.

Model Problem Base Instruction dikembangkan untuk melatih mahasiswa/siswa berkemampuan berpikir, mampu menyelesaikan masalah, dapat berperan menjadi orang dewasa, dan mandiri lewat penyelidikan autentik terhadap masalah-masalah keseharian. Model Problem Based Instruction menekankan pada penemuan konsep melalui 
serangkaian proses pembelajaran. Mahasiswa belajar bagaimana mengkonstruksi perolehan informasi dan pengembangan pemahaman tentang topik-topik, kerangka masalah, mengorganisasikan dan menginvestigasi masalah, mengumpulkan dan menganalisis data, menyusun fakta, mengkonstruksi argumentasi mengenai pemecahan masalah, bekerja secara individual atau kolaborasi dalam pemecahan masalah.

Model problem-based instruction memiliki lima langkah pembelajaran (Arend et al., 2001), yaitu: (1) Dosen mendefisikan atau mempresentasikan masalah atau isu yang berkaitan, (2) Dosen membantu mahasiswa mengklarifikasi masalah dan menentukan bagaimana masalah itu diinvestigasi (investigasi melibatkan sumber-sumber belajar, informasi, dan data yang variatif, melakukan surve dan pengukuran), (3) Dosen membantu mahasiswa menciptakan makna terkait dengan hasil pemecahan masalah yang akan dilaporkan (bagaimana mereka memecahkan masalah dan apa rasionalnya), (4) pengorganisasian laporan dengan makalah dan laporan lisan, dan (5) presentasi, pada proses ini mahasiswa dilatihkan untuk mampu mengkomunikasikan hasil yang diperoleh setelah melalui serangkaian proses pembelajaran.

Keterampilan proses atau metode ilmiah merupakan bagian dari sains (Subiyanto, 2008: 114). Mahasiswa mampu untuk menemukan konsep atau prinsip tau teori, untuk mengembangkan konsep yang telah ada sebelumnya, ataupun untuk melakukan penyangkalan terhadap suatu penemuan dengan menggunakan keterampilanketerampilan memproses perolehan pengetahuan (Indrawati, 2009: 3). Proses belajar mengajar dengan pendekatan keterampilan proses akan menciptakan kondisi belajar yang melibatkan mahasiswa serta aktif.

Keterampilan proses perlu diberdayakan dalam kegiatan belajar mengajar dikarenakan perkembangan ilmu pengetahuan berlangsung semakin cepat sehingga tidak mungkin lagi para guru mengajar semua fakta dan konsep kepada mahasiswa. Pengembangan konsep pada proses belajar mengajar tidak lepas dari perkembangan sikap dan nilai dalam anak didik. Oleh karena itu, pengembangan keterampilan dalam memperoleh data dan pengetahuan akan berperan sebagai wahana penyatu antara pengembangan konsep dan pengembangan sikap dan nilai (Conny, 2011: 14-16). Penilaian menurut Sayekti (2016) tidak hanya mentikberatkan pada penilaian kognitif saja tetapi dapat berupa penilaian-penilaian yang lain yang mendukung kegiatan

penanaman KPS pada peserta didik. Selaras dengan yang dijelaskan oleh Arif (2016: 125) bahwa dalam melakukan evaluasi KPS diperlukan berbagai cara dan teknik yang sesuai dengan hakikat sains itu sendiri. Untuk dapat mengetahui kemampuan belajar siswa dalam proses belajarnya, penilaian dilakukan harus fokus pada proses bukan pada produk sains.

\section{METODE PENELITIAN}

Penelitian dilaksanakan dengan menggunakan metode eksperimen semu (Quasi exsperimental research). Metode ini digunakan karena banyak dari subjek penelitian yang tidak dapat dikontrol atau dikendalikan (Darmadi, 2011:37). Tujuan penelitian eksperimen semu adalah mencari hubungan sebab-akibat dengan memberi perlakuanperlakuan tertentu pada dua kelompok eksperimen yaitu perlakuan tertentu pada 
kelompok eksperimen dan tanpa melakukan perlakuan tertentu untuk kelompok kontrol. Rancangan penelitian ini dapat dilihat pada tabel 1:

Tabel 1. Rancangan Penelitian Postest Only Control Group Design

\begin{tabular}{lcc}
\hline \multicolumn{1}{c}{ Kelompok } & Perlakuan & Post Tes \\
\hline Eksperimen (R) & $\mathrm{X}$ & $\mathrm{T}_{2}$ \\
Kontrol (R) & - & $\mathrm{T}_{2}$ \\
\hline
\end{tabular}

Keterangan:

$\mathrm{X}$ : Perlakuan yang diberikan kepada kelompok eksperimen yaitu dengan penggunaan model Problem Based Instruction

$\mathrm{T}_{2}$ : Tes akhir yang diberikan kepada kelompok eksperimen dan kelompok kontrol

$\mathrm{R}$ : Random assigment (pemilihan kelompok secara random)

Populasi dalam penelitian adalah seluruh mahasiswa Semester 2 Prodi PGSD IKIP PGRI Madiun. Teknik pengambilan sampel menggunakan cluster random sampling yang diambil dari mahasiswa semester 2 Prodi PGSD IKIP PGSD Madiun yang terdiri dari 2 kelas, yaitu kelas $2 \mathrm{D}$ sebagai kelas eksperimen dengan kelas 2C sebagai kontrol. Variabel bebas dalam penelitian adalah model Problem Based Instruction. Variabel terikat adalah keterampilan proses sains.

Teknik pengumpulan data yang digunakan dalam penelitian ini menggunakan metode tes dan metode non tes. Metode tes digunakan untuk memperoleh data keterampilan proses sains. Pertanyaan dalam tes dapat berupa tes tertulis maupun lisan. Tes yang digunakan berupa tes objektif yaitu bentuk pilihan ganda dan essay. Metode Non tes menggunakan teknik dokumentasi, observasi, wawancara dilakukan dengan mengumpukan data, mengambil catatan-catatan dan menelaah dokumen yang ada yang dimiliki kaitan dengan objek penelitian (Riduwan, 2011). Data yang dikumpulkan dengan teknik ini adalah data nilai mahasiswa.

Instrumen penilaian kemampuan keterampilan proses sains berupa tes essay, kemampuan kognitif yang digunakan berupa tes objektif. Soal tes yang digunakan sebelum digunakan untuk mengambil data penelitian, diujicobakan terlebih dahulu untuk mengetahui kualitas soal. Kelayakan instrumen yang digunakan dalam penelitian ini maka dilakukau uji kelayakan yang diuji dengan statistik meliputi uji validitas, uji reliabiitas, uji pembeda soal, uji indeks kesukaran.

Tujuan penelitian ini adalah untuk mengetahui taraf signifikansi efektifitas pembelajaran menggunakan model Problem Based Instruction pada mata kuliah konsep sains terhadap keterampilan proses sains mahasiswa. Persyaratan data statistik agar dapat diuji menggunakan paired t-test adalah sebaran data harus normal dan homogen. Uji prasyarat dilakukan sebelum uji hipotesis dengan paired t-test, uji prasayarat menggunakan uji Kolmogorv-Smirnov yang digunakan untuk uji normalitas sedangkan pada uji homogenitas digunakan uji dari Levene's.

\section{HASIL DAN PEMBAHASAN}

Data keterampilan proses sains mahasiswa diambil dari dua kelas yaitu kelas 2D sebagai kelas eksperimen menggunakan model Problem Based Instruction berjumlah 39 mahasiswa dan kelas 2C sebagai kelas kontrol dengan metode ceramah bervariasi 
berjumlah 36 mahasiswa. Deskripsi data keterampilan proses sains mahasiswa dapat dirinci dalam Tabel 2:

Tabel 2. Deskripsi Data Keterampilan Proses Sains

\begin{tabular}{lcc}
\hline \multicolumn{1}{c}{ Hasil Statistik } & \multicolumn{2}{c}{ Kelas } \\
\hline & Kontrol & Eksperimen \\
\hline Rata-rata & 63,09 & 80,37 \\
Standar Deviasi & 11,24 & 9,55 \\
Variansi & 120,63 & 88,75 \\
Nilai Minimum & 42,00 & 50,00 \\
Nilai Maksimum & 76,00 & 94,00 \\
Median & 66,67 & 80,00 \\
N & 36 & 39 \\
\hline
\end{tabular}

Uji normalitas dilakukan menggunakan uji Kolmogorov-Smirnov dengan $\alpha=0,05$ dan dibantu program SPSS 18. Jika nilai sig. dari uji normalitas lebih besar dari $\alpha$ (sig > 0,05) maka $\mathrm{H}_{0}$ diterima sehingga dapat dikatakan bahwa data terdistribusi normal. Uji normalitas data keterampilan proses sains dapat dilihat pada Tabel 3.

Tabel 3. Hasil Uji Normalitas Keterampilan Proses Sains

\begin{tabular}{lccc}
\hline \multicolumn{1}{c}{ Kelas } & N & Sig. & Keputusan \\
\hline Kontrol & 36 & 0.332 & Normal \\
Eksperimen & 39 & 0,538 & Normal \\
\hline
\end{tabular}

Tabel 3 menunjukkan bahwa nilai (sig.) > 0,05 sehingga keputusan uji $\mathrm{H}_{0}$ diterima. Hal ini dapat disimpulkan bahwa semua sampel pada penelitian ini berasal dari populasi yang berdistribusi normal.

Uji homogenitas menggunakan uji Levene's dengan $\alpha=0,05$ dengan bantuan program SPSS 18. $\mathrm{H}_{0}$ dinyatakan bahwa tiap kelas memiliki variansi yang sama (homogen). $\mathrm{H}_{1}$ dinyatakan bahwa tiap kelas tidak memiliki variansi yang sama. Homogenitas data keterampilan proses sains dapat dilihat pada Tabel 4.

Tabel 4. Hasil Uji Homogenitas Keterampilan Proses Sains

\begin{tabular}{cccc}
\hline $\mathrm{F}$ & Sig. & Keterangan & Keputusan \\
\hline 75 & 0,532 & Sig. $>0,05$ & Homogen \\
\hline
\end{tabular}

Tabel 4 menunjukkan bahwa nilai ( sig) $>0,05$ sehingga keputusan uji $\mathrm{H}_{0}$ diterima. Hal ini menunjukkan bahwa semua sampel berasal dari populasi yang variansinya homogen.

Uji hipotesis pada penelitian ini dilakukan dengan menggunakan uji-t. Data keterampilan proses sains mahasiswa pada penelitian dinyatakan normal dan homogen, sehingga prasyarat uji-t telah terpenuhi. Kriteria yang digunakan dalam pengambilan keputusan hipotesis adalah tingkat signifikasi $(\alpha)=0,05$ yaitu $\mathrm{H}_{0}$ ditolak jika signifikasi probabilitas $($ sig $)<\alpha(0,05)$. Hal ini berarti jika signifikasi probabilitas $($ sig $)<0,05$ maka hipotesis nihil $\left(\mathrm{H}_{0}\right)$ ditolak dan sebaliknya jika signifikasi probabilitas $(\mathrm{sig})>0,05$ maka hipotesis nihil diterima. 
Hasil uji efektivitas model pembelajaran Problem Based Instruction diperoleh dari data KPS melalui uji hipotesis. Hasil uji hipotesis data KPS disajikan pada Tabel 5

Tabel 5. Uji Hipotesis

\begin{tabular}{clll}
\hline Jenis Uji & \multicolumn{1}{c}{ Hasil } & \multicolumn{1}{c}{ Keputusan } & \multicolumn{1}{c}{ Kesimpulan } \\
\hline Paired Sample t-test & $\begin{array}{l}\mathrm{t}_{\text {hitung }}=-8,194 \\
\mathrm{p}=0,00\end{array}$ & $\mathrm{H}_{0}$ ditolak & $\begin{array}{l}\text { Hasil tidak sama (ada } \\
\text { beda) }\end{array}$ \\
& & & \\
\hline
\end{tabular}

Tabel 5 menunjukkan hasil keputusan uji $($ sig $)<0,050$ sehingga $\mathrm{H}_{1}$ diterima, hal ini berarti ada efektivitas model Problem Based Instruction terhadap keterampilan proses sains mahasiswa. Hal tersebut didukung dari nilai rata-rata keterampilan proses sains yaitu 60,39 pada kelas kontrol dan 81,57 pada kelas eksperimen, dengan selisih rata-rata yaitu 21,18. Rata-rata nilai keterampilan proses sains mahasiswa yang diperoleh kelas eksperimen lebih tinggi dibandingkan kelas kontrol. Hal tersebut dikarenakan melalui model Problem Based Instruction, guru mengajak mahasiswa untuk terlibat aktif baik secara fisik dan mental dalam belajarnya. Mahasiswa diajak aktif berpikir mengenali masalah, mengungkapkan gagasan-gagasan pemecahan masalah, merancang percobaan sendiri, melakukan percobaan sampai pada penyusunan kesimpulan.

Model Problem Based Instruction mengembangkan keterampilan proses sains mahasiswa karena mahasiswa dilatih untuk menemukan sendiri suatu konsep. Model Problem Based Instruction melatihkan bagaimana mahasiswa harus belajar. Dosen hanya berperan sebagai fasilitator. Hal tersebut sesuai dengan pernyataan Schlenker (Trianto, 2010) menyatakan bahwa latihan inkuiri dapat meningkatkan pemahaman sains, produktif dalam berpikir kreatif, dan siswa menjadi terampil dalam memperoleh dan menganalisis informasi. Model Problem Based Instruction merupakan model yang menyajikan masalah sebelum mahasiswa membangun pengetahuannya. Hal ini sesuai dengan pendapat Duch (2001) yang menyatakan bahwa Problem Based Instruction memberikan kesempatan untuk belajar bagaimana cara mereka belajar. Mahasiswa dilatih untuk menyusun sendiri pengetahuannya, mengembangkan keterampilan pemecahan masalah, mandiri serta meningkatkan kepercayaan diri melalui proses pembelajaran.

Pembelajaran dengan model Problem Based Instruction diawali dengan tahapan merumuskan masalah melalui wacana pada LKS. Tahapan selanjutnya adalah merumuskan hipotesis. Mahasiswa dibentuk dalam kelompok-kelompok diskusi belajar sehingga mahasiswa dapat berkolaborasi dan berinteraksi. Hal tersebut sesuai dengan pernyataan Setiawan (2008:56) mengungkapkan bahwa pengkonstruksian pengetahuan secara bersama-sama melalui diskusi kelompok memungkinkan mahasiswa mengungkapkan gagasan, mendengarkan pendapat orang lain dan bersama-sama membangun pengertian.

Tahapan kedua adalah merancang percobaan, mendorong mahasiswa untuk lebih memahami masalah yang akan dipecahkan dan saling mengemukakan ide-ide untuk mengembangkan pemahaman mahasiswa. Mahasiswa berpikir mengenai alat dan bahan yang diperlukan, cara kerja yang harus dilakukan, dan cara mentabulasikan data yang 
diperoleh. Tahap ini melatihkan keterampilan dalam merencanakan percobaan melalui pemahaman konsep, menentukan alat dan bahan, menentukan langkah kerja pada tahap selanjutnya.

Tahapan ketiga adalah pengumpulan data melalui kegiatan percobaan. Percobaan memberikan kesempatan mahasiswa mengembangkan keterampilan analisis (analysis). Hal tersebut sesuai dengan pernyataan Hackling (2005) yang mengungkapkan bahwa praktik penyelidikan lapangan memberikan kesempatan siswa untuk berlatih dan mengembangkan keterampilan menginvestigasi serta mendapatkan pengalaman nyata. Melalui kegiatan percobaan mahasiswa akan belajar untuk menemukan sebuah konsep. Tahapan ini melatihkan keterampilan melakukan percobaan yang meliputi keterampilan menggunakan peralatan dalam memperoleh suatu pengetahuan.

Tahapan keempat adalah analisis data akan melatihkan mahasiswa belajar aktif dan memberi kesempatan kepada mahasiswa untuk berpikir sendiri, mahasiswa akan termotivasi dalam belajar, melatihkan kemampuan menemukan informasi, meningkatkan semangat ingin tahu, dan kemampuan bertanya mahasiswa. Hal tersebut sesuai dengan pernyataan Callahan, et. al. (2009: 293-294) menyatakan bahwa dalam kegiatan menganalisa data dapat dilakukan dengan membangun dan menggunakan ideide yang dimiliki siswa. Pada tahapan ini, mahasiswa dapat melatihkan aspek kemampuan mengkomunikasikan hasil pengamatan, analisis data, dan pembahasan.

Tahapan kelima adalah membuat kesimpulan. Tahapan ini melatihkan mahasiswa dapat membedakan penjelasan dan penelitian dan mampu menyusun hubungan berdasarkan pada bukti dan argumen logis. Melalui pembelajaran yang menekankan pada proses mahasiswa akan dibiasakan untuk mengembangkan keterampilanketerampilan yang dimiliki untuk menemukan dan mengkonstruksikan sendiri konsep yang telah dipelajari.

\section{SIMPULAN}

Berdasarkan hasil penelitian dapat disimpulkan pembelajaran dengan menggunakan model Problem Based Instruction efektif untuk memberdayakan keterampilan proses sains dilihat dari hasil uji hipotesis dengan perolehan signifikansi sebesar 0,00 $<0,05$ dengan demikian penerapan model Problem Based Instruction dapat dijadikan sebagai alternatif model dalam mengembangkan pembelajaran yang inovatif dan kreatif dalam mencapai tujuan pembelajaran.

\section{DAFTAR PUSTAKA}

Depdiknas. 2008. Panduan Pengembangan Bahan Ajar. Jakarta: Direktorat Pendidikan Dasar dan Menengah.

Drake. 2014. The "Ideal" vs "Real" Value Educator: How Teachers' Practice Impacts on Value Education at a Disadvantaged South African School. Mediterranean Journal of Social Sciences Vol. 5 No. 20 September 2014 ISSN (online) 20392117, ISSN (prin) 2039-9340. 
Hake, R.R. 1998. Intercrative Engagement Versus Tradisional Method: A SixThousand-Student Survey of Mechanics Test Data fpr Introductory Physics Courses. American Assosiation of Physics Teachers. 66, hlm. 64-74.

Handayani, C. D., T. Jalmo, dan Pramudiyati. 2014. Pengaruh Bahan Ajar Modul Remedial terhadap Hasil Belajar Kognitif Siswa. Jurnal Bioterdidik.Vol 2 No 4, 2014.

M.C. Liu dan J. Y. Wang. 2010. Investigating Knowledge Integration in Web-based Thematic Learning Using Concept Mapping Assessment. Educational Technology \& Society, 13(2), hlm. 25-39.

Majid, Abdul. 2014. Pembelajaran Tematik Terpadu. Bandung: PT Remaja Rosdakarya.

Nilasari Efi, Ery Try Djatmika, dan anang Santoso. 2016. "Pengaruh Penggunaan Modul Pembelajaran Kontekstual Terhadap Hasil Belajar Siswa Kelas V Sekolah Dasa"r. Jurnal Pendidikan: Teori, Penelitian, dan Pengembangan Volume: 1 Nomor: 7 Bulan Juli Tahun 2016 Halaman: 1399-1404. Tersedia secara online EISSN: 2502-471X.

Ningsih, Pudji Hariati. "Pengaruh Penggunaan Modul dan Penggunaan Buku Paket terhadap Prestasi Belajar Mata Pelajaran IPS Siswa Kelas V SDN Sukabumi 10". Jurnal Penelitian dan Pendidikan IPS (JPPI) Volume 9 No 2 (2015) 12101218. ISSN (Print): 1858-4985. http://ejournal.unikama.ac.id/index.php/JPPI.

Prastowo. 2014. Pengembangan Bahan Ajar Tematik. Jakarta: Kencana.

Santrock. 2010. Psychology Pendidikan Edisi 2. (Penerjemah Tri Wibowo). Jakarta: Kencana Prenada Media Group.

Saputra, Henry Januar dan Nur Isti Faizah. 2017. "Pegembangan Bahan Ajar Untuk Menumbuhkan Nilai Karakter Peduli Lingkungan Pada Siswa Kelas IV Sekolah Dasar. Jurnal Profesi Pendidikan Dasar Vol. 4, No. 1. Juli. Hlm. 62-74. http://journals.ums.ac.id/index.php/ppd/article/view/3956.

Subekti, Tabah. 2016. "Pengembangan Modul Bahasa Indonesia Bermuatan Karakter Nilai Kebangsaan Bagi Mahasiswa PGSD. Jurnal Profesi Pendidikan Dasar, Vol. 3. No. 2. Desember, hlm. 92-101. http://journals.ums.ac.id/index.php/ppd /article/view/2746

Sugiyono. 2015. Metode Penelitian Kuantitatif, Kualitatif, dan R\&D. Cetakan ke-22. Bandung: Alfabeta.

Trianto. 2011. Desain Pengembangan Pembelajaran Tematik Bagi Anak Usia Dini TK/RA \& Anak Kelas Awal SD/MI. Jakarta: Kencana Prenada Media Group. 